\title{
RELACIONAMENTOS CORPORATIVOS E REDES SOCIAIS ON-LINE EM UM MUNDO DE CONSUMIDORES: COABITAÇÃO E RESPEITO NO CASO ME GUSTA PICOLÉS ARTESANAIS
}

\author{
Corporate relationships and online social networks in a \\ consumer world: cohabitation and respect in the case $\mathrm{Me}$ \\ Gusta Picolés Artesanais
}

\section{Relacionamientos organizacionales y redes sociales en línea en un mundo de consumidores: cohabitación y respeto en el caso Me Gusta Picolés Artesanais}

\author{
Marcelo Pereira da Silva \\ Universidade Estadual Paulista de Bauru, São Paulo, Brasil. \\ Doutor em Comunicação pela Universidade Metodista de São Paulo. Professor do curso de Relações Públicas \\ da Universidade Federal do Maranhão. Pesquisador de pós-doutorado em Comunicação Midiática pela \\ Universidade Estadual Paulista de Bauru. \\ E-mail: marcelosilva_rp@hotmail.com
}

\section{Gleicilene Pereira Setúbal \\ Universidade Federal do Maranhão, Maranhão, Brasil. \\ Graduanda no curso de Relações Públicas da Universidade Federal do Maranhão. \\ E-mail: gleyci.setubal@gmail.com}

\section{Kaiane da Conceição Costa \\ Universidade Federal do Maranhão, Maranhão, Brasil. \\ Graduanda no curso de Relações Públicas da Universidade Federal do Maranhão. \\ E-mail: kayannecosta@gmail.com}

\section{Mônica Rayanne Garces Ramos \\ Universidade Federal do Maranhão, Maranhão, Brasil. \\ Graduanda no curso de Relações Públicas da Universidade Federal do Maranhão. \\ E-mail: monicagramos5@gmail.com}

\begin{abstract}
RESUMO Sob a égide da sociedade pós-moderna, este artigo apresenta a comunicação a partir dos riscos aos quais está imersa no contexto das redes sociais on-line, posto que hoje deve lidar com públicos mais alertas, céticos, ativos e insatisfeitos com os desconfortos e decepções que permeiam a relação com as organizações no que tange às práticas e experiências de consumo. Nesse cenário, jogamos luz sobre o posicionamento positivo da marca Me Gusta Picolés Artesanais, por meio de um estudo de caso após um casal homossexual em 2015 ser expulso do estabelecimento em São Paulo e a reverberação que o caso gerou na ágora virtual. PALAVRAS-CHAVE Comunicação, Relacionamento, Redes sociais on-line, Me Gusta Picolés Artesanais, Consumo.
\end{abstract}

ABSTRACT Under the aegis of a postmodern society, this article presents communication under the perspective of the risks it is submitted to in the context of online social networks, considering it must deal today with audiences that are more alert, skeptical, active, and unsatisfied with the discomforts and disappointments that permeate the relationship with corporations regarding 
consumption practices and experiences. In this scenario, we highlight the positive positioning taken by the "Me Gusta Picolés Artesanais" trademark through a case study after a homosexual couple was thrown out from its store in São Paulo in 2015 and the repercussion generated by the case in the virtual agora.

KEYWORDS Communication, Relationship, Online social networks, Me Gusta Picolés Artesanais, Consumer.

RESUMEN Bajo la égida de la sociedad posmoderna, este texto presenta la comunicación a partir de los riesgos a los cuales está inmersa en el contexto de las redes sociales en línea, ya que hoy debe lidiar con públicos más céticos, activos e insatisfechos con las decepciones que permean la relación con las organizaciones en lo que se refiere a las prácticas y experiencias de consumo. En esta perspectiva, analizamos el posicionamiento de la marca Me Gusta Picolés Artesanais en un estudio de caso, después que una pareja homosexual en 2015 fue expulsada del establecimiento de la empresa en São Paulo y la repercusión que el caso generó en el mundo virtual.

PALABRAS CLAVE Comunicación, Relacionamiento, Redes sociales en línea, Me Gusta Picolés Artesanais, Consumo.

\section{INTRODUÇÃO}

Na sociedade pós-moderna - dependente e permeada pela tecnologia -, em que os públicos utilizam as redes sociais on-line e o aparato tecnológico que está à sua disposição, se destaca a comunicação de risco, que se difere das outras pelo fato de, através dela, se produzir uma comunicação de mão dupla, em que o fluxo das mensagens e informações entre o emissor e receptor são facilitadas, tornando mais eficiente a participação e a manifestação dos stakeholders.

A capacidade de expressão e compartilhamento entre os sujeitos potencializou-se no cenário tecnológico atual. Com isso, a velocidade na troca de informações proporciona maior facilidade na exposição de críticas, injúrias e difamação das organizações na web. As empresas precisam compreender o perfil do seu consumidor e, portanto, pautar suas ações em uma comunicação transparente, dialogal e dialógica, primando por relacionamentos duradouros e saudáveis com seus públicos-chave.

O princípio de atender, respeitar e ouvir deve ser prioridade, visto que estabelecer, manter e aprimorar as relações entre as organizações e seus clientes deve gerar benefícios para todos, sobretudo, a possibilidade da convivência no, muitas vezes selvagem, modus operandi do sistema capitalista de concorrência.

Semprini (2006) defende que as relações com os públicos estratégicos constituem o elemento basilar da comunicação da marca; portanto, a atenção e o respeito às mediações e manifestações crescem de modo vertiginoso, sobretudo na ágora virtual. As marcas devem investir tempo para nutrir, reafirmar e reforçar o relacionamento com seus interlocutores.

Nesse sentido, nosso artigo aborda o posicionamento da empresa Me Gusta Picolés Artesanais, em 2015, após um casal homossexual ser expulso do estabelecimento dela em São Paulo, levantando questionamentos a respeito da importância das corporações adotarem relacionamentos mais abertos, honestos e pessoais com os seus públicos no contexto de uma sociedade que é essencialmente plural. Ademais, coloca na ribalta a coabitação e a convivência respeitosa como um dos desafios para uma vida social menos norteada por conflitualidade, ódio e desrespeito. 


\section{A SOCIEDADE PÓS-MODERNA: ALGUMAS CONSIDERAÇÕES}

Os avanços tecnológicos nos proporciona, em tese, o aproveitamento do tempo para a realização de atividades que levam à melhoria da qualidade de vida da sociedade, tornaria os indivíduos mais solidários e proativos, preparados para lidar com eventuais situações de risco, dilemas e controvérsias.

Entretanto, justamente o fato dos homens terem obtido desenvolvimento material, levou-os a diminuírem como pessoas - no sentido humano -, haja vista que muitas vezes apenas levam em conta o que pode vir a lhe garantir algum tipo de retorno. Bauman (2007) afirma que a sociedade se tornou líquida em todos os campos e que a denominada "Era da liquidez" faz com que os valores diluam-se como a água que escorre em nossas mãos.

É possível que o imediatismo social seja responsável pela inconstância, já que o ser humano vive em busca do que "está pronto" e que poderá garantir satisfação instantânea; os objetos se tornam mais valorosos que os homens, então a luta é para ser aceito pelos demais, a boa imagem é fulcral para uma boa posição social. A vida na sociedade líquido-moderna "é como uma versão perniciosa da dança nas cadeiras, cujo prêmio é a garantia temporária de ser excluído das fileiras dos destruídos e evitar ser jogado no lixo" (BAUMAN, 2007, p. 10).

Diante disso, Bauman salienta que as instituições sofrem certo "derretimento" para dar lugar aos objetivos individuais que são guiados pelo desenrolar do mundo capitalista, onde se tem a falsa sensação de liberdade, as crenças são desmontadas e remodeladas em alta velocidade; não há um caráter reflexivo, a vida corrida e a premissa de que tudo precisa ser vivido - e rápido - não permite reflexões sobre as ações individuais e coletivas.

A intolerância dos públicos diante de tudo aquilo que de alguma forma consideram como desvio de conduta - ou que destoa dos padrões - é reprovado, cabendo ressignificar-se para atender aos "estatutos" sociais; isso não é diferente na relação entre os consumidores e as corporações. A sociedade que em diversas ocasiões lutou por liberdade tornou-se prisioneira de novos dogmas guiados pelo consumismo. Lipovetsky (2007, p. 38) afirma que entramos na fase do capitalismo chamada de hiperconsumo, na qual:

nasce um terceiro tipo de Homo consumericus, voraz, móvel, flexível, liberto das antigas culturas de classe, imprevisível nos seus gostos e nas suas compras e sedento de experiências emocionais e de (mais) bem-estar, de marcas, de autenticidade, de imediaticidade, de comunicação. Tudo se passa como se, doravante, o consumo funcionasse como um império sem tempos mortos cujos contornos são infinitos. Mas estes prazeres privados originam uma felicidade paradoxal: nunca 0 indivíduo contemporâneo atingiu tal grau de abandono.

Sobre isso, Baudrillard (2008, p. 15) destaca o "espetáculo permanente da celebração do objeto na publicidade e as centenas de mensagens diárias” veiculadas nos diferentes veículos. Essa celebração da vida pela publicidade veiculada nos Media não é uma simples relação entre "meios manipuladores e dóceis audiências" (CANCLINI, 2010, p. 59), mas de sujeitos ativos que participam de um processo de negociação.

A obsolescência programada tornou-se a essência da sociedade de consumo e da consumolatria. O consumismo espreita os sujeitos na 
medida em que a sociedade de consumidores inferioriza a durabilidade, equiparando os termos "velho" e "defasado", impróprios para seguir sendo utilizados, ou seja, são destinados à lata de lixo. A reduzida expectativa de vida de um produto faz parte das estratégias de marketing no cálculo dos lucros e no envolvimento do consumidor, o que ocorre, segundo Bauman (2008, p. 31), mediante a "apoteose das novas ofertas (de hoje) e a difamação das antigas (de ontem)”.

É nesse contexto que as organizações duelam por fatias de mercado e tentam gerir a comunicação, considerando que os públicos têm voz ativa, espaço para expressar decepções e reverberar o que julgam como práticas equivocadas e inaceitáveis das corporações. Essa é uma realidade com a qual as organizações devem lidar.

\section{A COMUNICAÇÃO DE RISCO NA SOCIEDADE PÓS-MODERNA}

A comunicação de risco foi o termo utilizado por Marchiori e Lourenço (2012), ao referenciar Beck (2007), no qual trata de um movimento teórico da década de 1980 em que se consegue identificar indícios de uma nova transformação na sociedade por conta de alguns eventos e incidentes trágicos que ocorreram no período, mas também por questões ligadas aos riscos à saúde e ao meio ambiente. Desse ponto, a sociedade desperta e passa a se preocupar com as questões que a envolvem; em prol disso, a comunicação de risco se desenvolve com a finalidade de proteger os cidadãos, tanto de riscos tecnológicos e naturais como dos artificiais.

Para Beck (2007 apud MARCHIORI; LOURENÇO, 2012, p. 3), os riscos estão relacionados com os eventos negativos - e/ou insólitos - vivenciados pelas pessoas diante das mudanças e demandas sociais; tais riscos são inerentes aos seres humanos e presentes onde existem ações humanas. Portanto, a função da comunicação de risco é estabelecer uma visão ampliada dos riscos que a sociedade está sendo submetida.

Falar em comunicação de risco é compreendê-la como um processo estratégico das organizações, cuja finalidade trabalha os riscos, a fim de evitar que se tornem algo maior e prejudicial aos atingidos pelo acontecimento, ou seja, que se materializem e se transformem em possíveis crises. Entender esse processo é primar pela diferenciação dos relacionamentos, construindo uma interação entre a organização e seus públicos. (MARCHIORI; LOURENÇO, 2012, p. 1)

A comunicação de risco permite uma comunicação de mão dupla, em que o fluxo das mensagens e das informações entre o emissor e receptor são facilitadas, tornando mais fácil a participação e a interatividade. As organizações precisam adotar uma postura "aberta" e transparente, favorecendo laços de confiança e credibilidade de seus públicos, que estão cada vez mais atentos, céticos e exigentes em relação às suas atitudes, defende Marchiori e Lourenço (2012); nessa mesma linha, Rinaldi (2010) afirma que a comunicação de risco deve ser adotada pelas organizações como processo estratégico enleado à governança corporativa.

É certo que a sociedade, hoje, se informa rapidamente sobre determinado assunto, fato ou notícia, mesmo que involuntariamente; a informação é considerada como fator mais que relevante nas situações de risco, em especial nas catástrofes. Os sujeitos sentem a necessidade de informação. Credibilidade e confiança são peças-chave que contribuem para o comprometimento e aceitação do público por parte de uma 
organização. Quanto menos as pessoas desconhecem uma informação, mais tendem a se preocupar com os riscos e passam a percebê-los bem maiores do que são, assim, pessoas mal informadas são mais inseguras, desconfiadas e menos receptivas à comunicação.

Rinaldi (2010) acredita que a comunicação de risco contribui com a gestão corporativa pelo fato de melhorar a governabilidade, as relações entre as partes interessadas (públicos de interesse), e proporcionar mais transparência às ações e discursos organizacionais. Isso é crucial para a administração das marcas em uma sociedade conectada por meio das mídias digitais. A tecnologia e o potencial das redes sociais virtuais desenham um quadro relevante nesse contexto da informação defendido por Marchiori e Lourenço (2012), indo ao encontro do que Gonçalves e Silva (2014, p. 85-86) pontuam, já que a interatividade possibilitada pelas mídias sociais digitais proporciona uma nova possibilidade de relacionamento, "diminuindo as distâncias entre os interlocutores, potencializando cada ator e, consequentemente, contribuindo para um processo comunicacional mais horizontalizado".

\section{INTERNET E PRÁTICAS DE CONSUMO: ALINHAVANDO UNIVERSOS}

A Internet tornou possível a ampliação do âmbito comunicacional, que deixou de ser unidirecional (via única), como o caso da televisão, e tornouse multidirecional. $\mathrm{O}$ consumidor não somente recebe passivamente produtos, informações e serviços, mas ganha espaço para avaliar, externar sua opinião e compartilhá-la com milhares de usuários. Hoje mais de um bilhão de pessoas acessam sites de relacionamento e, de acordo com pesquisa da Nielsen (PESQUISA..., 2012) - provedora global de informações -, $68 \%$ dos usuários usam as redes sociais para avaliar produtos e serviços. Cabe destacar que atualmente, de acordo com Kotler, Kartajaia e Setiawan (2010), há mais confiança nos relacionamentos horizontais do que nos verticais, posto que os consumidores acreditam mais uns nos outros do que no discurso das empresas.

Apesar de todas as possibilidades para auxiliar a criação de uma imagem positiva para as organizações ou pessoa pública que a Internet oferece, a ideia de que é um lugar sem regras inibe investimentos no setor de mídias digitais; isso ocorre porque:

Diante desse cenário, o temor, por parte das organizações, de receber opiniões negativas e possivelmente de sofrer prejuízos à reputação corporativa tende a aumentar, devido, sobretudo, ao foco mercadológico e à ausência de capacitação para relacionamento no uso das redes. (VERGILI, 2014, p. 12)

Investir em mídias digitais possibilita não apenas um meio de propagandear produtos, serviços e eventos, mas de criar relacionamento com o consumidor; seu comportamento convida as organizações a uma comunicação mais voltada aos princípios e políticas de relações públicas. Antes de realizar uma compra, o usuário recorre às redes sociais virtuais para medir a reputação da empresa, haja vista que existe uma gama de sites de opinião ${ }^{1}$ que funcionam como termômetro para o comprador saber se o produto/serviço oferecido é de qualidade

1. Como o Reclame Aqui, que é considerada uma das maiores plataformas de reclamação e pesquisa do consumidor brasileiro. 
ou se os problemas apresentados por consumidores são, amiúde, resolvidos pelas organizações.

A análise/avaliação feita por outros clientes pode ser determinante para a escolha da marca, por isso, é necessário que os profissionais que lidam diretamente com o público nas mídias digitais estejam alinhados com o posicionamento da empresa, pois:

As redes são dinâmicas, envolvem diferentes sujeitos e cosmovisões, extrapolam em amplitude a vivência presencial, transcendem barreiras geográficas e culturais e aumentam o potencial da informação, permitindo a construção de um perfil público e o envolvimento com uma lista de usuário, para criar, fortalecer vínculos, estabelecer inúmeras conexões por meio do aparato tecnológico. (GONÇALVES; SILVA, 2014, p. 87)

A mesma Internet que oferece uma série de vantagens apresenta enormes riscos à reputação empresarial. Como símbolo da pósmodernidade, por conectar o mundo instantaneamente, dar voz e expressividade à liberdade de expressão e ao código do consumidor - que foi promulgado em 1990 (BRASIL, 1990), visando estabelecer normas de proteção e defesa do consumidor -, qualquer erro pode tomar grandes proporções, desarranjando a imagem e reputação construídas em anos de trabalho.

\section{RELAÇÕES PÚBLICAS, IDENTIDADE, IMAGEM, REPUTAÇÃO E RELACIONAMENTO}

A identidade e os valores de uma empresa mostram seu diferencial enquanto organização e servem como carta de apresentação aos públicos de interesse. A representação dessa identidade, unida ao impacto causado em seus públicos, gera o que chamamos de imagem corporativa. A reputação de uma organização, por sua vez, está diretamente ligada à sua imagem no mercado e é construída a partir do momento em que suas práticas condizem com o discurso apregoado em seus valores, fazendo com que seus ideais sejam demonstrados na prática, por meio da qual a comunicação empresa-públicos se torna transparente e dialogal, dando maior segurança e credibilidade aos públicos envolvidos.

Segundo Argentini referenciado por Vergili (2014, p. 56), a reputação é algo mais duradouro, que "[...] se diferencia de imagem por ser construída ao longo do tempo e por não ser simplesmente uma percepção em um determinado período”. Além disso, para Vergili (2014), a reputação pode ser entendida como um conjunto de atributos favoráveis, dada a corporação ou pessoa por segmentos de públicos, considerando-a idônea, ética e digna de crédito no desempenho de suas atividades e na colocação em prática de sua retórica. É uma condição os gestores relembrarem o público de interesse das virtudes da marca.

Com base nessa reflexão, uma empresa pode possuir várias imagens presentes em cada segmento da sociedade. O que uma organização faz para resolver o problema apresentado pelo consumidor torna-se mais importante do que o próprio problema; assim, a imagem e reputação de uma corporação dependem, primordialmente, da maneira como ela se porta perante as situações polêmicas e conflituosas. Reconhecer a relevância que cada indivíduo possui - e deixá-lo ciente disso - é fundamental para toda corporação, pois tendo a confiança de seus 
públicos e transmitindo-lhes segurança, o enfrentamento da crise pode se solucionar com menos dificuldade ou, até mesmo, gerar um saldo positivo em termos de imagem e reputação.

Para isso, torna-se crucial que a empresa esteja preparada para lidar com esse tipo de acontecimento, tenha planejamento prévio, bem como possua profissionais que saibam orientar os envolvidos a como se portar diante da imprensa e demais canais de divulgação de notícias; caso contrário, as consequências podem ser desastrosas para a organização, facilitando a exposição da marca de modo negativo.

Dentre os canais de divulgação de notícias da atualidade, destacamos as redes sociais digitais. Com o avanço da Internet e a consolidação da globalização, a disseminação de notícias acontece em tempo real, instantâneo e é determinante na formação da opinião pública. Ao mesmo tempo, o mundo on-line aparelha o usuário de tal modo que:

A possibilidade de um processo de troca fluido e uma interação de "igual para igual" tem estimulado o surgimento de plataformas virtuais voltadas aos interesses do consumidor, nas quais as organizações não têm outra saída, ou respondem às reclamações veiculadas em posts, ou arcam com o ônus decorrente da exposição negativa de sua marca para um número altíssimo de usuários. (GONÇALVES; SILVA, 2014, p. 89)

A nova ecologia da comunicação que a tecnologia engendra, em conjunto com a emergência de redes sociais conectadas, permitiu o aprimoramento dos sistemas de mensuração de reputação corporativa adquirida ao longo do tempo. A oportunidade de se verificar as opiniões de diversos usuários que, em algum momento, já interagiram com a empresa, possibilitou o cruzamento de informações e, consequentemente, uma estimativa do comportamento do usuário em relação à empresa.

A capacidade de diálogo entre os sujeitos potencializou-se no cenário tecnológico atual. Com isso, a velocidade na troca de informações proporciona maior facilidade na exposição de críticas, injúrias e difamação das organizações na web. Ademais, acreditamos que o ambiente virtual ampliou a dificuldade de gestão do relacionamento com os stakeholders pelo fato de assumirem o papel de usuários-mídia, ou seja, produtores de conteúdo e não apenas receptores de mensagens.

Desse modo, admitir os erros e saber lidar com as reclamações, quando o fato tem fundamento, é imprescindível nesse ambiente, até para evitar reverberações e possíveis danos à imagem/reputação corporativas.

A relação com os públicos é muito relevante, posto que eles constroem a imagem da marca, sendo que as organizações dependem deles para garantir sua sobrevivência em um mercado competitivo. Diante desse aspecto, as relações públicas tornam-se emergentes por possuírem como função-base o estreitamento dos relacionamentos entre empresa e públicos de interesse, além de manterem o diálogo contínuo, fortalecendo o laço afetivo e o respeito às demandas dos públicos. Ademais, "a gestão da reputação, nos dias de hoje, requer ampla abordagem para o monitoramento de mídia, sem que a marca seja encarada apenas do prisma dos veículos de informação tradicionais e da perspectiva do controle dado pela publicidade” (VERGILI, 2014, p. 59).

As redes sociais permitem, ainda, o agravamento de crises de reputação, uma vez que permitem a divulgação, compartilhamento e replicabilidade de notícias referentes a qualquer deslize da organização. As corporações precisam estar preparadas para lidar com a situação pós- 
ocorrido, ou mesmo preparar-se previamente com um plano estratégico, prevendo possíveis “ataques” à determinada ação ou posicionamento.

Se uma empresa tem atitudes equivocadas e questionáveis, suas estatísticas de reputação caem rapidamente e só um realinhamento das estratégias corporativas pode fazê-la se recuperar. O posicionamento da organização é fulcral para a manutenção de sua reputação ou seu desarranjo, como verificamos no caso Me Gusta Picolés Artesanais.

\section{RELACIONAMENTOS CORPORATIVOS E REDES SOCIAIS ON-LINE: $O$ CASO ME GUSTA PICOLÉS ARTESANAIS}

As redes sociais virtuais são as primeiras a anunciarem - e replicarem -, antes de qualquer outro meio, as percepções dos stakeholders, em especial dos clientes, no que tange às experiências de consumo. Percepções estas relacionadas à prestação de atendimento ou à qualidade - e problemas - de determinado produto; o mundo on-line constitui um ambiente em que o consumidor tem seu espaço de expressão e coloca sua opinião sem ressalvas.

Portanto, entendemos as páginas de relacionamento como uma central de atendimento ao cliente que funcionam 24 horas por dia; elas são fundamentais para a organização, pois os consumidores as utilizam como "palanque" para reclamar, acusar e avaliar os serviços prestados, a qualidade dos produtos e a rapidez no acompanhamento e solução dos problemas que surgem no binômio organização/consumidor.

Tendo em vista que as empresas devem estar inseridas e fazer parte dos nichos em que seu público/consumidor se encontra, elas se lançam em um ambiente extremamente interativo, criativo e produtivo, mas, ao mesmo tempo, composto por um sistema que provoca insegurança, desrespeito e intolerância.

$\mathrm{Na}$ esteira desse pensamento, apresentamos o caso que ocorreu em uma loja do ramo de sorvetes artesanais, a Me Gusta; a empresa atua no setor alimentício há menos de três anos, com venda de picolés artesanais inspirados nas paletas mexicanas, na cidade de São Paulo. No domingo, 8 de março de 2015, o jornalista Raul Perez e seu namorado foram expulsos da paleteria nos Jardins, área nobre de São Paulo, porque estavam se beijando dentro do estabelecimento.

Supostamente incomodado com o beijo, um casal heterossexual queixou-se a funcionários da Me Gusta Picolés Artesanais e um dos seguranças teria mandado os jovens saírem do local sob o pretexto de que "era um ambiente familiar" (IRAHETA, 2015). Após o ocorrido, um dos jovens - Raul - providenciou uma denúncia ao Centro de Combate à Homofobia, vinculado à Prefeitura de São Paulo e publicou seu relato no seu perfil pessoal do Facebook.

Nos Jardins, fui expulso de uma paleteria (rs) por beijar meu namorado. O segurança disse que aquele era um ambiente familiar. Só mais um domingo nos Brasis. (COMENTÁRIO..., 2015a)

O post, como era de se esperar, gerou indignação pelo suposto ato preconceituoso do segurança, porém, inicialmente, o caso ficou restrito apenas aos amigos que acompanhavam o perfil do jornalista e aos consumidores que presenciaram a cena no estabelecimento. A situação ganhou foco quando a empresa Me Gusta se pronunciou, no dia seguinte, utilizando a mesma rede social digital, como podemos constatar: 
Este é um pedido oficial de desculpas. [...] estamos profundamente tristes e perplexos com o ocorrido. Queremos nos retratar publicamente com o casal. Por eles terem passado pela degradante situação [...]. A culpa não é exclusiva do funcionário. Não é também só do outro casal que se sentiu incomodado. A culpa é da Me Gusta. Trabalhamos com pessoas. Não só com picolés! Devemos saber da conduta das pessoas que empregamos em nosso estabelecimento. Devemos orientar e situar nossos funcionários no século XXI. Devemos investir em debate e treinamento pessoal para que essa situação nunca chegue a existir. Devemos focar nossa comunicação na tolerância e falar abertamente de amor ao próximo e humanidade. (RESPOSTA..., 2015)

O pedido de desculpa emitido pela paleteria mostrou um posicionamento que, pela linguagem utilizada, carrega aspectos humanos, de sensibilidade, colocando a marca no mesmo "nível” de seu público; mas fez mais: assumiu o erro pelo incômodo ocorrido. Uma posição avessa poderia gerar possíveis conflitos com os stakeholders da marca e outros públicos de afinidade, como os grupos de pressão, os ativistas ligados aos direitos humanos, das minorias e dos homossexuais.

A resposta imediata, o discurso direto, a empatia exposta e a "emoção" que povoa o discurso da Me Gusta, provocaram uma repercussão positiva com os usuários/mídia que acompanharam a publicação. $\mathrm{O}$ post, considerando os dados atuais, rendeu 3.844 compartilhamentos, 21.205 curtidas. Por meio de seu posicionamento, a marca alcançou uma amplitude maior de públicos, os quais podem ter construído uma percepção favorável dela.

Deu vontade de conhecer a loja e os produtos só pelo lindo posicionamento da marca perante o ocorrido. Lindo. (COMENTÁRIO..., 2015b)

Nem conheço a Me Gusta, mas pela humildade com que retratou já merece meu respeito. Espero que isso ultrapasse as redes sociais. (COMENTÁRIO..., 2015c)

Em virtude do ocorrido, em 14 de março de 2015 a Me Gusta deu início ao evento Me Gusta Toda Forma de AMOR. A intenção do evento, analisando a posição da marca, seria mais um pedido oficial e público de desculpas da marca; a proposta parece ter sido bem recebida e 1,1 mil de usuários/mídia prometeram comparecer ao evento. Essa questão corrobora a fragilidade das marcas na pós-modernidade (SEMPRINI, 2006) e o papel ativo do consumidor conectado, bem como dos públicos de afinidade aos temas publicitários, crises e conflitos decorrentes das relações de consumo.

As empresas devem estar cientes que seu público não mais se satisfaz em apenas ter o produto - ou serviço - e consumi-lo em seguida. $\mathrm{O}$ público carece entrar em relacionamento com a corporação, haja vista que, apesar da extroversão peculiar ao brasileiro, a falta de capacitação nas/das organizações, assim como a necessidade urgente de resultados fazem com que os funcionários - que deveriam ser embaixadores da marca - ajam, muitas vezes, de forma robótica, despreparada e, até, rude.

O posicionamento e a abordagem escolhida pela corporação devem ser o tipo de posicionamento que os stakeholders aparentam querer na prática das organizações. É necessário pensar além de estratégias e ações de caráter social e de sustentabilidade, é preciso voltar ao básico, oferecer coisas simples para que o cliente se sinta especial, respeitado 
e cuidado. É preciso investir em capacitação, abrindo mão da margem de lucro "agora". O princípio de atender com excelência tem que estar em primeiro lugar, também de respeitar, ser tolerante e administrar as diferenças na pluralidade social em que estamos inseridos.

O caso Me Gusta vai ao encontro do que defende Vergili (2014) e Gonçalves e Silva (2014), visto que adotar uma relação de interação de "igual para igual" com o consumidor significa entender que esse contato, se realizado por meio de uma comunicação excelente, aproximando o consumidor, ouvindo suas críticas e negociando sentidos, pode gerar sujeitos mais dispostos a replicar as ações/reações das marcas, tanto positivas como negativas. Mais ativos mediante as mudanças tecnológicas, o consumidor está mais consciente de seu papel, não aceita ser ludibriado nem a intolerância em relação às minorias e convida à valorização do ser humano em seu sentido mais amplo.

Todas as corporações estão vulneráveis à crise, seja ocasionada por motivos simples ou por catástrofes, posto que

As redes sociais disseminam notícias tão rapidamente que chega a ser inacreditável, e quem as comanda é um sujeito capaz de produzir enunciações que podem colocar em xeque o planejamento e as estratégias desenvolvidos durante anos, assim como a imagem e reputação das organizações. (GOLLNER, 2015, p. 93)

O discurso pessoal e a sensibilidade da Me Gusta - ainda que no nível discursivo - evidenciam um posicionamento diferenciado, pautado em uma comunicação que reforça o atendimento com boas práticas: empatia, cordialidade, atitudes prestativas, busca por soluções e coragem para assumir os riscos advindos do fato de assumir, publicamente, seu erro.

As corporações precisam estabelecer vínculos com seus clientes, não apenas para gerarem lucro, mas para tornar os públicos mais satisfeitos, o que poderá fomentar uma reputação referenciada, ancorada em valores de uma marca que sabe escutar e se relacionar com os consumidores, engajando-se em suas preferências, idiossincrasias, decepções e opiniões. Para isso, é relevante o estabelecimento de práticas para atuar no atendimento ao público: mais que isso, as organizações devem ter um posicionamento honesto e sincero sobre temas polêmicos, atuando com verdade, respeito e abertura.

Uma comunicação organizacional voltada para o estabelecimento de relacionamentos duradouros e respeitosos com os públicos de interesse pode gerar relevância social, construir e manter uma boa reputação para as corporações no contexto de uma sociedade complexa, frágil e volátil como a pós-moderna: reconhecimento, relacionamento, relevância e reputação são uma condição sine qua non na gestão das organizações e de suas marcas, tanto no mundo on-line quanto no off-line.

O universo vislumbrado pelas marcas (pro)põe ao sujeito esquematizações sígnicas organizadas e atraentes, sugere sistemas simbólicos que o levam a pensar o mundo, considerando sua fragilidade e pluralidade (SEMPRINI, 2006); nesse contexto, o discurso da Me Gusta traz à ribalta noções de coerência e unidade a partir de experiências discrepantes e contraditórias; ensina-nos sobre quem somos, mais que isso: nos auxilia a assumir os erros que cometemos e a agir com verdade e honestidade, algo impensável em uma sociedade perpassada pela corrupção e interesses escusos. 
A empresa Me Gusta mostra-se aberta à convivência e avessa à intolerância de seu funcionário - o que pode afetar o tecido social; considerando o cenário que desenhamos, a Me Gusta levou a efeito uma comunicação de risco, apresentou atitudes coerentes com as indignações geradas pelo inconveniente em sua loja e fez com que a marca tivesse mais visibilidade, valorização e respeito depois do ocorrido.

Além de prezar por um relacionamento mais pessoal com seus públicos, o caso Me Gusta pode ter contribuído com a positivação da sua reputação e fez ser valorizada por sua atuação diante da atitude preconceituosa do casal heterossexual que estava na loja e de seu funcionário; longe de qualquer julgamento que dicotomize a questão em "certo" ou "errado", cremos que um dos maiores desafios da sociedade pós-moderna reside na administração das conflitualidades e na escolha da coabitação e da compaixão como pilares para a construção de um mundo mais justo e respeitoso.

\section{CONSIDERAÇÕES FINAIS}

Há um esforço por parte de administradores e gestores da comunicação no fomento de engajamento do consumidor em relação às marcas; assim, não seria demasiado, a nosso ver, que considerassem os arranjos e modalidades de subjetivação emergentes dentro dos sistemas de coletividade como as redes sociais da Internet, as quais estão enleadas de visões de mundo que se materializam em ideologias e categorias de pensamento significativas para a constituição da identidade corporativa e o delineamento da missão da empresa enquanto mediação sociocultural.

O caso Me Gusta Picolés Artesanais lança luz sobre a exposição das marcas no contexto da amplificação dos espaços de expressão e do potencial de replicabilidade das redes sociais digitais. A empresa poderia ter evitado o percalço, mas ela, diferentemente do que ocorre amiúde, trouxe à tona sua ciência em relação ao erro que cometeu e conseguiu, de certa forma, levar ao público algo que ele deseja: ser ouvido, respeitado e valorizado na sua diferença.

É necessário que as organizações invistam cada vez mais na excelência da comunicação, desenvolva planos de engajamento de clientes, ouvidorias, pesquisas etc., meios que as interliguem a seus públicos de interesse e aos públicos de afinidade. Fulcral que tenham uma imagem corporativa pautada na verdade e em práticas que levem em consideração as demandas de seus consumidores - e públicos de pressão -, posto que eles devem ser ouvidos e compreendidos, tornando-se uma marca (re) conhecida por escutar seus públicos e preocupada com suas preferências, opiniões, orientações e visões de mundo.

Semprini (2006) defende que é inegável a influência das marcas na vida dos sujeitos; todavia, paradoxalmente, elas encontram-se mais expostas aos "ventos" do ecossistema virtual, ficando sujeitas à fragilização e à vulnerabilidade, próprias da pós-modernidade.

As empresas devem fazer com o que o consumidor perceba a exclusividade com que é tratado e reforçar o atendimento com boas práticas, como empatia, cordialidade, atitudes prestativas e soluções. A gestão das conflitualidades que surgem na ágora virtual ajuda as organizações na construção de identidades mais coerentes, equilibrando o discurso e a práxis. Muitas vezes, a árvore da informação e seus frondosos ramos da transmissão escamoteiam a floresta da comunicação 
e das alteridades. O discurso de resposta da Me Gusta corrobora esse pensamento: o outro não pode ser apenas o outro, mas o outro igual a nós, digno de respeito e amor.

Na esteira de Canclini (2010, p. 70), pensamos que a atividade de consumo pode levar o sujeito a uma participação mais ativa nas decisões ligadas à política corporativa; para tanto, há necessidade de articulação entre consumo e exercício da cidadania, que requer uma oferta diversificada de bens - signos/objetos -, informação pluridimensional e verossímil sobre a qualidade de produtos, objetos e serviços e uma participação mais democrática dos sujeitos.

Se essas ações fizerem parte da práxis das organizações, os consumidores acenderiam à condição de cidadãos; assim, teríamos uma concepção de mercado para além da ideia de permuta de mercadorias, adentrando a uma noção de consumo como prática sociocultural interativa que movimenta um universo no qual o valor mercantil passa a habitar o plano social, cultural e interativo, não apenas o "objeto físico".

Em um mundo perpassado pela fragilidade, as marcas devem levar em conta que o fácil acesso às várias plataformas de mídia tornou o público "mais empoderado para desafiar políticas corporativas" (JENKINS; FORD; GREEN, 2014, p. 85). Assim, as diversas formas de participação ativa do público, por meio de "comunidades de marcas", fiscalizando o comportamento organizacional, bem como observando e denunciando as empresas que não agem em conformidade com o interesse de seus consumidores, são pilares da cultura da propagabilidade erigida com as redes sociais da Internet.

Destarte, Bauman (2008, p. 8) pondera que as sociedades constituem fábricas de significações, "sementeiras da vida com sentido". Como as sociedades, as organizações igualmente são um viveiro de significações; portanto, podem ancorar sob o medo ou sobre a confiança, o que é sempre uma escolha e comporta uma decisão. O sentido do medo do outro ou da confiança nele depende da ruptura da ética da competitividade e a implantação, ipso facto, da noção de solidariedade e compaixão ao universo das marcas, tanto no mundo off-line quanto no on-line. Coabitar é preciso, sobretudo, em uma sociedade plural e caleidoscópica, ainda que isso traga alguns dissabores.

\section{REFERÊNCIAS}

BAUDRILLARD, J. A sociedade de consumo. Lisboa: Edições 70, 2008.

BAUMAN, Z. Vida líquida. Rio de Janeiro: Zahar, 2007.

Vida para consumo: transformação das pessoas em mercadoria. Rio de Janeiro: Zahar, 2008 .

BRASIL. Presidência da República. Casa Civil. Lei no 8.078, de 11 de setembro de 1990. Dispõe sobre a proteção do consumidor e dá outras providências. Diário Oficial da União, Brasília, DF, 12 set. 1990. Seção 1, p. 1. Suplemento. Disponível em: <https://goo.gl/P7nUD>. Acesso em: 11 dez. 2014.

CANCLINI, N. G. Consumidores e cidadãos: conflitos multiculturais da globalização. Rio de Janeiro: URFJ, 2010

COMENTÁRIO usuário Facebook. Me Gusta Picolés Artesanais. [S.I.], 2015. Facebook. Disponivel em: <https://goo.gl/3KfXp6>. Acesso em: 18 abr. 2015a.

COMENTÁRIO usuário Facebook. Me Gusta Picolés Artesanais. [S.I.], 2015. Facebook. Disponível em: <https://goo.gl/3KfXp6>. Acesso em: 18 abr. 2015b.

COMENTÁRIO usuário Facebook. Me Gusta Picolés Artesanais. [S.I.], 2015. Facebook. Disponivel em: <https://goo.gl/3KfXp6>. Acesso em: 18 abr. 2015c. 
GOLLNER, A. P. Páginas de fãs, anúncios direcionados e outras soluções do Facebook a serviço da comunicação organizacional digital. In: GOULART, E. E. Mídias sociais: uma contribuição de análise. Porto Alegre: Edipucrs, 2015.

GONÇALVES, E. M.; SILVA, M. A amplitude do diálogo nas redes sociais digitais: sentidos em construção. In: GOULART, E. E. Mídias sociais: uma contribuição de análise. Porto Alegre: Edipucrs, 2014

IRAHETA, D. Paleteria pede desculpas após funcionário expulsar casal gay da loja na zona nobre de São Paulo. HuffPost Brasil, São Paulo, 2015. Disponível em: <https://goo.gl/ qUMjnR>. Acesso em: 18 abr. 2015.

JENKINS, H.; FORD, S.; GREEN, J. Cultura da conexão: criando valor e significado por meio da mídia propagável. São Paulo: Aleph, 2014.

KOTLER, P.; KARTAJAIA, H.; SETIAWAN, I. Marketing 3.0: as forças que estão definindo o novo marketing centrado no ser humano. Rio de Janeiro: Elsevier, 2010.

LIPOVETSKY, G. A felicidade paradoxal: ensaio sobre a sociedade do hiperconsumo. São Paulo: Companhia das Letras, 2007.

MARCHIORI, M.; LOURENÇO, M. R. A prática da comunicação de risco nas organizações. Facesi em Revista, Ibiporã, ano 4, v. 4, 2012.

PESQUISA global sobre mídias sociais. Nielsen, Cotia, 1 ago. 2012. Disponível em: <https:// goo.gl/rPF1mt>. Acesso em: 18 abr. 2015.

RESPOSTA Me Gusta. Me Gusta Picolés Artesanais. [S.I.], 2015. Facebook. Disponível em: <https://goo.gl/3KfXp6>. Acesso em: 30 set. 2015.

RINALDI, A. A importância da comunicação de risco para as organizações. São Paulo: Sicurezza, 2010.

SEMPRINI, A. A marca pós-moderna: poder e fragilidade da marca na sociedade contemporânea. São Paulo: Estação das Letras, 2006.

VERGILI, R. Relações públicas, mercado e redes sociais. 1. ed. São Paulo: Summus, 2014 